\title{
Anabases
}

ANABASES Traditions et réceptions de l'Antiquité

$7 \mid 2008$

Varia

\section{Albert UDERZO, Caelum in caput eius cadit}

\section{Olivier Devillers}

\section{OpenEdition \\ Journals}

Édition électronique

URL : http://journals.openedition.org/anabases/2596

DOI : 10.4000/anabases. 2596

ISSN : 2256-9421

\section{Éditeur}

E.R.A.S.M.E.

\section{Édition imprimée}

Date de publication : 1 mars 2008

Pagination : 314

ISSN : 1774-4296

\section{Référence électronique}

Olivier Devillers, «Albert uderzo, Caelum in caput eius cadit », Anabases [En ligne], 7 | 2008, mis en ligne le 01 décembre 2011, consulté le 22 septembre 2020. URL : http://journals.openedition.org/anabases/ 2596 ; DOI : https://doi.org/10.4000/anabases.2596

Ce document a été généré automatiquement le 22 septembre 2020.

(c) Anabases 


\title{
Albert UDERZO, Caelum in caput eius cadit
}

\author{
Olivier Devillers
}

\section{RÉFÉRENCE}

Albert UDERZo, Caelum in caput eius cadit, Traduit en latin par Annie Collognat, Paris, Les

Éditions Albert René, 2007, 56 p.

9,90 euros / ISBN 978-2-86497-208-2.

1 Cette traduction latine de la dernière aventure d'Astérix (Le ciel lui est tombé sur la tête) est l'œuvre d'Annie Collognat. Présidente de l'Association Pallas, vouée à promouvoir la connaissance de l'Antiquité et l'étude dans langues anciennes, en interaction avec l'actualité culturelle (http://pallas.zeblog.com), celle-ci joue la carte de la pédagogie. À l'album proprement dit - peut-être pas le plus réputé de la collection Astérix, mais assurément l'un des plus audacieux dans sa conception (notamment à travers la rencontre avec l'univers de Disney, Decemnasutus) -, est joint en effet un cahier pédagogique de huit pages composé de trois parties : une présentation des personnages mettant l'accent sur le rapport entre leur nom et leur caractère ou rôle dans l'histoire (ex.: il n'est pas facile de trouver un mode de vie paisible avec le poissonnier Modusvivendix); un lexique donnant, page par page (les exclamations et les interjections courantes sont rassemblées à la fin), le vocabulaire, avec toutefois un regret, le fait que les verbes ne sont pas accompagnés de la mention de leurs temps primitifs; un bref commentaire de 28 citations latines présentes dans le texte (où elles sont signalées par l'italique). Par ce dernier aspect, principalement, cet album pourra assurément servir de point de départ à des incursions dans les domaines de la littérature et de la civilisation latines, domaines auxquels le scénario de l'histoire irruption d'aliens dans le village des Gaulois - ne se prête guère. Quant au texte latin lui-même, il se lit facilement et agréablement; certaines pages en particulier 
pourraient constituer un support utile pour une révision de la syntaxe de la phrase simple (on épinglera l'usage de l'infinitif d'exclamation).

\section{AUTEURS}

\section{OLIVIER DEVILLERS}

Université Michel de Montaigne-Bordeaux 3

oldevillers@wanadoo.fr 